\title{
First discovery of adventive populations of Trissolcus japonicus in Europe
}

\author{
Judith Stahl ${ }^{1,2} \cdot$ Francesco Tortorici $^{3} \cdot$ Marianna Pontini $^{3} \cdot$ Marie-Claude Bon $^{4} \cdot$ Kim Hoelmer $^{5} \cdot$ Cristina Marazzi $^{6}$. \\ Luciana Tavella $^{3} \cdot$ Tim Haye $^{1}$
}

Received: 26 September 2018 / Revised: 23 October 2018 / Accepted: 27 October 2018 / Published online: 31 October 2018

(c) The Author(s) 2018

\begin{abstract}
The brown marmorated stink bug, Halyomorpha halys (Stål), native to East Asia, emerged as an invasive pest in Europe in the 2000s. In its native range, Trissolcus japonicus (Ashmead) is the dominant egg parasitoid of $H$. halys, and thus it has been considered for classical biological control in countries invaded by the pest. A survey of native egg parasitoids conducted in 2017 and 2018 with frozen, sentinel egg masses of $H$. halys revealed that $T$. japonicus was already present in apple orchards in the Canton Ticino, Switzerland. Trissolcus japonicus was recovered in both years and from three different sites. In total, 17 egg masses were recovered from which 42 adult parasitoids emerged. A genetic analysis using the barcode mitochondrial DNA confirmed the morphological identification of T. japonicus and evidenced a best match of the "Ticino populations" to Japanese populations, but the pathways of entry remain unknown.
\end{abstract}

Keywords Biological control $\cdot$ Egg parasitoids $\cdot$ Halyomorpha halys $\cdot$ Scelionidae

\section{Key message}

Communicated by D.C. Weber.

Electronic supplementary material The online version of this article (https://doi.org/10.1007/s10340-018-1061-2) contains supplementary material, which is available to authorized users.

Judith Stahl

j.stahl@cabi.org

1 CABI, Rue des Grillons 1, 2800 Delémont, Switzerland

2 Institute of Ecology and Evolutionary Biology, University of Bremen, Leobener Str. NW2, 28359 Bremen, Germany

3 Dipartimento di Scienze Agrarie, Forestali e Alimentari (DISAFA), ULF Entomologia Generale e Applicata, University of Torino, Largo P. Braccini 2, 10095 Grugliasco, TO, Italy

4 European Biological Control Laboratory, USDA Agricultural Research Service, Campus International de Baillarguet, Montferrier le Lez, France

5 Beneficial Insects Introduction Research Unit, USDA Agricultural Research Service, Newark, DE, USA

6 Dipartimento delle finanze e dell'economia, Servizio fitosanitario cantonale, Sezione dell' agricoltura viale S. Franscini 17, 6501 Bellinzona, Switzerland
- Surveys for egg parasitoids of Halyomorpha halys were conducted in south-eastern Switzerland.

- For the first time, the Asian parasitoid T. japonicus was recovered from sentinel $H$. halys egg masses in Europe.

- Trissolcus japonicus is established in Switzerland and was found in two consecutive years at three different sites.

- Parasitism levels by T. japonicus are currently low, with a maximum of $2 \%$.

\section{Introduction}

The brown marmorated stink bug, Halyomorpha halys (Stål) (Hemiptera: Pentatomidae), is native to East Asia (China, Japan, and the Korean peninsula) and has emerged as an invasive pest in North America and Europe in the 1990s and 2000s, respectively (Hoebeke and Carter 2003; Haye et al. 2015). It is highly polyphagous, feeding on over 170 plant species in at least 12 families (Rice et al. 2014; Leskey and Nielsen 2018), causing economic losses to a wide variety of crops in invaded areas, and having a particularly devastating 
economic impact in tree fruit (e.g. apples, peaches, pears), and hazelnuts in the USA, Italy, and Georgia (United States Apple Association 2010; Maistrello et al. 2017; Bosco et al. 2018). As the application of broad-spectrum insecticides is the most widely used strategy for managing $H$. halys in Europe, more environmentally friendly and self-sustaining control measures, such as classical or augmentative biological control, are urgently needed for an area-wide control of H. halys.

Throughout its native range, $H$. halys is heavily attacked by a wide variety of hymenopteran egg parasitoids in the genera Trissolcus Ashmead, Telenomus Haliday (Scelionidae), Ooencyrtus Ashmead (Encyrtidae) and Anastatus Motschulsky (Eupelmidae) (reviewed in Lee et al. 2013). Surveys in north-eastern China have shown that the dominant parasitoid of $H$. halys is Trissolcus japonicus (Ashmead), with parasitism levels often ranging from 50 to $90 \%$ (Qiu et al. 2007; Yang et al. 2009; Zhang et al. 2017) and thus, this species has been considered as a classical biological control agent in invaded areas in North America and Europe.

The native geographic range of $T$. japonicus widely overlaps with that of $H$. halys, including Japan, China, Taiwan, and the Republic of Korea (Qiu et al. 2007; Yang et al. 2009; Zhang et al. 2017). Bioclimatic envelope models predict that $T$. japonicus could establish in $H$. halys infested areas in Europe and North America (Avila and Charles 2018), and in fact adventive populations have already been discovered in the USA [Beltsville, Maryland in 2014 (Talamas et al. 2015); Vancouver, Washington in 2015 (Milnes et al. 2016); Portland, Oregon in 2016 (Hedstrom et al. 2017)] and have since been reported in 10 states (Morrison et al. 2018). The pathway(s) of entry for T. japonicus in North America remains unknown, and is presumed to be the same as for the introduction of $H$. halys (Talamas et al. 2015).

In Europe, several native species have been reared from sentinel $H$. halys egg masses, including Anastatus bifasciatus (Geoffroy) (from both viable and frozen eggs), Trissolcus cultratus (Mayr) (frozen eggs) (Haye et al. 2015; Abram et al. 2017), Ooencyrtus telenomicida (Vassiliev) (frozen eggs) (Roversi et al. 2016), and some Trissolcus and Telenomus spp. (viable eggs) (LT, FT, unpublished data). Most of the native European Trissolcus species have been reported to oviposit in $H$. halys eggs, but their offspring are unable to develop, and thus, the exotic host is considered as evolutionary trap for native scelionid parasitoids (Schlaepfer et al. 2005; Haye et al. 2015). This phenomenon has also been observed in North American scelionids (Abram et al. 2014). Surveys for egg parasitoids in Europe have been restricted to western Switzerland (Haye et al. 2015) and northern Italy (Roversi et al. 2016; Costi 2018) and to date no adventive populations of T. japonicus have been detected. Halyomorpha halys has been introduced several times into Europe, with evidence of multiple invasions from different source populations (Gariepy et al. 2015; Cesari et al. 2018). As $T$. japonicus may use the same pathways of entry as its host $H$. halys, we considered that this species may eventually arrive in Europe as well. Therefore, the exposure of sentinel $H$. halys egg masses was extended to include the Ticino in south-eastern Switzerland to ensure more complete coverage of the areas where populations of $H$. halys are established.

\section{Materials and methods}

\section{Exposure of sentinel eggs}

In 2017, a total of $226 \mathrm{H}$. halys sentinel egg masses were exposed between August and September in a conventionally managed apple orchard in the municipality of Bellinzona, Canton of Ticino, Switzerland (site 1, 46 $09^{\prime} 42.1^{\prime \prime} \mathrm{N}$ $\left.8^{\circ} 58^{\prime} 12.2^{\prime \prime} \mathrm{E}\right)$. Sentinel egg masses used for exposure were collected from host plants and mesh parts of cages of the laboratory rearing at CABI in Delémont, Switzerland, without the use of water when they were less than $24 \mathrm{~h}$ old. They were immediately frozen at $-80{ }^{\circ} \mathrm{C}$ for a maximum of 1 month and thawed no more than 2 days before the exposure. Rearing methods for $H$. halys have been described in detail in Stahl et al. (2018). All eggs were counted before field exposure, and only egg masses consisting of at least 20 eggs were used for exposure. Egg masses were glued directly on the underside of tree leaves $50 \mathrm{~cm}$ to $180 \mathrm{~cm}$ above ground, using 'Cementit' (merz + benteli AG, Niederwangen, Switzerland). Leaves of various host plants taken from the $H$. halys laboratory rearing cages were placed next to the egg masses and fixed with twist ties to potentially increase the chance of parasitism by presenting an array of chemical cues. Exposure lengths varied between 4 and 6 days. After field exposure, recovered eggs were counted and predation by chewing and sucking predators was assessed under a Leica routine stereo microscope M50 with a magnification of up to $40 \times$ (see Morrison et al. 2016). All egg masses were then kept at $26^{\circ} \mathrm{C}$ and monitored for parasitoid emergence for the following 6 weeks. Newly emerged parasitoids were provided with fresh (unfrozen) egg masses to test whether their offspring could complete development. All parasitoids that emerged from egg masses, both exposed in the field and in the laboratory, were stored in $99 \%$ ethanol.

In 2018, surveys for parasitoids were extended, and a total of $710 \mathrm{H}$. halys egg masses were exposed between May and August at five sites around Bellinzona, including the same site as in 2017 (site 1) and four additional sites in the same municipality (Table 1). The new sites included two conventionally managed mixed fruit orchards (apple, persimmon, pear, cherry, plum) (site $2,46^{\circ} 09^{\prime} 34.2^{\prime \prime} \mathrm{N}$ $8^{\circ} 56^{\prime} 03.3^{\prime \prime} \mathrm{E}$, and site $3,46^{\circ} 09^{\prime} 57.1^{\prime \prime} \mathrm{N} 8^{\circ} 56^{\prime} 37.9^{\prime \prime} \mathrm{E}$ ), one 
Table 1 Parasitism and predation of frozen H. halys egg masses exposed at various sites in the Canton Ticino, Switzerland, in 2017 and 2018

\begin{tabular}{|c|c|c|c|c|c|c|c|c|}
\hline Exposure date & Location & $\begin{array}{l}\text { Egg masses } \\
\text { (eggs) } \\
\text { exposed }\end{array}$ & $\begin{array}{l}\text { Egg masses } \\
\text { (eggs) } \\
\text { recovered }^{\text {a }}\end{array}$ & $\begin{array}{l}\text { Egg masses (eggs) } \\
\text { attacked by chew- } \\
\text { ing predators }\end{array}$ & $\begin{array}{l}\text { Egg masses (eggs) } \\
\text { attacked by suck- } \\
\text { ing predators }\end{array}$ & $\begin{array}{l}\text { Egg masses } \\
\text { (eggs) } \\
\text { parasitized }^{\text {b }}\end{array}$ & $\begin{array}{l}\% \text { Para- } \\
\text { sitism } \\
\text { (total) }\end{array}$ & $\begin{array}{l}\% \text { Parasit- } \\
\text { ism by } T . \\
\text { japonicus }\end{array}$ \\
\hline \multicolumn{9}{|l|}{2017} \\
\hline 3-10 Aug & 1 & $25(637)$ & $20(416)$ & 12 (49) & $2(2)$ & $1(16)$ & 3.9 & 0 \\
\hline 10-17 Aug & 1 & $146(3767)$ & $141(3004)$ & 95 (546) & $6(18)$ & $17(77)$ & 2.6 & 0.2 \\
\hline \multicolumn{9}{|l|}{2018} \\
\hline \multirow[t]{6}{*}{ 17-22 May } & 1 & $20(541)$ & 19 (427) & $10(103)$ & $0(0)$ & $1(1)$ & 0.2 & 0 \\
\hline & 2 & $20(543)$ & $15(320)$ & $2(8)$ & $0(0)$ & $0(0)$ & 0 & 0 \\
\hline & 3 & $20(531)$ & 19 (434) & $4(7)$ & $0(0)$ & $0(0)$ & 0 & 0 \\
\hline & 4 & $20(540)$ & $17(373)$ & $9(60)$ & $0(0)$ & $1(16)$ & 4.3 & 0 \\
\hline & 5 & 20 (496) & $16(328)$ & $7(32)$ & $1(1)$ & $3(13)$ & 4.0 & 0 \\
\hline & Total & $100(2651)$ & $86(1882)$ & $32(210)$ & $1(1)$ & $5(30)$ & 1.6 & 0 \\
\hline \multirow[t]{6}{*}{ 20-25 Jun } & 1 & $50(1343)$ & $46(1127)$ & $11(42)$ & $0(0)$ & $1(4)$ & 0.4 & 0 \\
\hline & 2 & $20(526)$ & $11(172)$ & $8(80)$ & $0(0)$ & $0(0)$ & 0 & 0 \\
\hline & 3 & $20(542)$ & 13 (226) & $14(170)$ & $0(0)$ & $2(38)$ & 16.8 & 0 \\
\hline & 4 & $20(535)$ & $10(227)$ & $13(175)$ & $0(0)$ & $1(12)$ & 5.3 & 0 \\
\hline & 5 & $20(550)$ & $12(231)$ & $6(80)$ & $0(0)$ & $3(20)$ & 8.7 & 0 \\
\hline & total & $130(3496)$ & 93 (2018) & $52(547)$ & $0(0)$ & $7(74)$ & 3.7 & 0 \\
\hline \multirow[t]{6}{*}{ 19-25 Jul } & 1 & 75 (1985) & $64(1555)$ & $12(46)$ & $6(36)$ & $0(0)$ & 0 & 0 \\
\hline & 2 & $20(508)$ & $16(355)$ & $13(42)$ & $0(0)$ & $3(37)$ & 10.4 & 0 \\
\hline & 3 & $20(500)$ & $21(202)$ & $9(94)$ & $0(0)$ & $4(35)$ & 17.3 & 0 \\
\hline & 4 & 20 (496) & $6(118)$ & $14(234)$ & $0(0)$ & $1(7)$ & 5.9 & 0 \\
\hline & 5 & $20(501)$ & 7 (129) & 11 (137) & $0(0)$ & $1(16)$ & 12.4 & 0 \\
\hline & Total & 155 (3990) & $104(2373)$ & $59(553)$ & $6(36)$ & $9(95)$ & 4.0 & 0 \\
\hline \multirow[t]{3}{*}{ 25-30 Jul } & 1 & 140 (3717) & 137 (3489) & $12(19)$ & $2(2)$ & $7(38)$ & 1.1 & 0.06 \\
\hline & 6 & $30(757)$ & 27 (612) & $14(85)$ & $0(0)$ & $0(0)$ & 0 & 0 \\
\hline & Total & $170(4474)$ & $164(4101)$ & $26(104)$ & $2(2)$ & $7(38)$ & 0.9 & 0.06 \\
\hline $30 \mathrm{Jul}-4$ Aug & 6 & 98 (2507) & 85 (1797) & $38(246)$ & $0(0)$ & $12(27)$ & 1.5 & 0.2 \\
\hline 08-13 Aug & 1 & 105 (2697) & 95 (2125) & 48 (292) & $3(4)$ & $2(21)$ & 1.0 & 0 \\
\hline \multirow[t]{6}{*}{ 13-17 Aug } & 2 & $20(516)$ & $18(383)$ & $16(107)$ & $0(0)$ & $0(0)$ & 0 & 0 \\
\hline & 3 & $20(537)$ & $17(335)$ & $11(161)$ & $0(0)$ & $0(0)$ & 0 & 0 \\
\hline & 4 & $20(517)$ & $16(290)$ & $12(152)$ & $1(10)$ & $1(6)$ & 2.1 & 2.1 \\
\hline & 5 & $20(541)$ & $10(240)$ & 7 (115) & $0(0)$ & $0(0)$ & 0 & 0 \\
\hline & 6 & 63 (1677) & 57 (1356) & 28 (146) & $5(18)$ & $11(22)$ & 1.6 & 1.3 \\
\hline & Total & 185 (4808) & 118 (2604) & 74 (681) & $6(28)$ & $11(22)$ & 0.8 & 0.5 \\
\hline
\end{tabular}

${ }^{a}$ Egg masses that contained at least one egg that had not been attacked by either chewing or sucking predators after recollection ${ }^{\mathrm{b}}$ Parasitism measured by parasitoid offspring emergence of recovered eggs

conventional orchard with apple and pear trees (site 5, $\left.46^{\circ} 13^{\prime} 12.4^{\prime \prime} \mathrm{N} 9^{\circ} 03^{\prime} 11.4^{\prime \prime} \mathrm{E}\right)$, and one private garden with peach trees (site $4,46^{\circ} 09^{\prime} 30.0^{\prime \prime} \mathrm{N} 8^{\circ} 59^{\prime} 21.0^{\prime \prime} \mathrm{E}$ ). Once per month, 15-135 frozen egg masses were exposed at every site on apple or peach trees and five additional egg masses were exposed in the closest available natural site nearby (shrubs, hedges, etc.). Additionally, egg masses (in total 191) were exposed three times in an organic apple orchard located near the Italian border in the municipality of Manno, Canton of Ticino, Switzerland

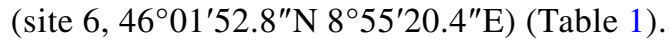

\section{Morphological identification of parasitoids}

Ethanol-stored specimens were dried and glued on cardpoints for morphological analyses. A Leitz large-field stereo microscope TS with magnification up to $160 \times$ and a spot light Leica CLS 150X were used for morphological diagnosis. For Scelionidae, Telenomus species were determined 
using the keys of Kozlov and Kononova (1983) and Johnson (1984), and Trissolcus species were identified using the keys by Talamas et al. (2017). Moreover, Trissolcus specimens were compared with pictures of holotype and paratypes in Hymenoptera Online (HOL) and in Talamas et al. (2017). Anastatus individuals were identified using the key by Askew and Nieves-Aldrey (2004). All the specimens used for morphological analysis were deposited in the Natural History Museum of Bern, Switzerland (NMBE) and Dipartimento di Scienze Agrarie, Forestali e Alimentari (DISAFA) (ESM1).

\section{Molecular confirmation}

Morphological identification of T. japonicus was confirmed molecularly at the DISAFA as a routine procedure. In total, two males and three females of $T$. japonicus from the Ticino and, as a positive control, one female from the CABI colony (China) were processed (ESM1). Genomic DNA was extracted according to Gariepy et al. (2014), and the barcode region of the cytochrome oxidase I (COI) gene was amplified using universal PCR primers for insects [LCO1490 (5'-GGT CAA CAA ATC ATA AAG ATA TTG G-3') and HCO-2198 (5'-TAA ACT TCA GGG TGA CCA AAA AAT CA-3') (Folmer et al. 1994)]. The PCR was performed in a $50 \mu \mathrm{l}$ reaction volume: $2 \mu \mathrm{l}$ of DNA, $37.9 \mu \mathrm{l}$ molecular grade water, $5 \mu$ l 10X Qiagen PCR buffer, $3 \mu$ dNTPs (25 mM each), $1.5 \mu \mathrm{l} \mathrm{MgCl}_{2}, 0.2 \mu \mathrm{l}$ of each primer $(0.3 \mu \mathrm{M}$ each), $0.2 \mu \mathrm{l} \mathrm{Taq}$ DNA Polymerase (Qiagen, Hilden, Germany). Thermocycling conditions were optimized to shorten reaction times and included initial denaturation at $94{ }^{\circ} \mathrm{C}$ for $300 \mathrm{~s}$, followed by 35 cycles of $94^{\circ} \mathrm{C}$ for $30 \mathrm{~s}$, annealing at $52{ }^{\circ} \mathrm{C}$ for $45 \mathrm{~s}$ and extension at $72{ }^{\circ} \mathrm{C}$ for $60 \mathrm{~s}$; then further $600 \mathrm{~s}$ at $72{ }^{\circ} \mathrm{C}$ for final extension. All PCR products were purified using a commercial kit (QIAquick PCR Purification Kit, Qiagen GmbH, Hilden, Germany) following the manufacturer's instructions and sent for sequencing in one direction using the forward primer to an external service (Genechron S.r.l., Rome, Italy).

The same sequence of $612 \mathrm{bp}$ in length was obtained in all samples and compared with sequences present in the GenBank database by similarity search using the Basic Local Alignment Search Tool (http://www.ncbi.nlm.nih. gov/BLASTn) confirming the taxonomy of all morphologically identified specimens. All residual DNA is archived at DISAFA.

\section{Genetic matching with Asian populations of Trissolcus japonicus}

We used the barcode approach to identify and exclude Asian T. japonicus populations that were highly divergent from the "Ticino population." Mounted specimens (three males and three females) recovered from three parasitized egg masses from Ticino were shipped to EBCL along with 10 females from the laboratory colony kept in the quarantine at CABI Switzerland, which originated from the Beijing Province, China (ESM1). Genomic DNA from all specimens was extracted according to Gariepy et al. (2014), except those from mounted specimens which were non-destructively isolated as described in Giantsis et al. (2015). Amplification of all barcode sequences and their analysis were done as described in Ganjisaffar et al. (2018). All sequences of $674 \mathrm{bp}$ in length generated from this study are deposited in the GenBank (Table 2), and all residual DNA extracts are archived at EBCL (Table 2). Of note, when this study was initiated, only 24 barcodes were deposited in the GenBank database. Twenty-three of the 24 are from Japan and most are published by Matsuo et al. (2014). For this study, we had access to a not yet published EBCL database of 127 barcodes of T. japonicus mostly from laboratory colonies derived from natural populations collected in China, Korea, Japan and USA (EBCL custom database). Searches for sequence similarity against this database confirmed the close similarity of the "Ticino sequence" with those of Japanese origin. Therefore, the 26 sequences generated from this study were aligned with 10 "Japanese T. japonicus" sequences from this custom database and 22 sequences retrieved from GenBank following the procedure described in Ganjisaffar et al. (2018). Two sequences from GenBank were not considered in our data set as the sequences were not of adequate length. The final alignment of 58 barcode sequences of $423 \mathrm{bp}$ in length revealed a total of six haplotypes. The phylogenetic relationships among these haplotypes were depicted using statistical parsimony in TCS as implemented in PopART (Leigh and Bryant 2015). This approach also enabled us to display the geographical distribution of all haplotypes analysed.

\section{Results}

\section{Exposure of sentinel eggs}

Between August and September 2017 and from May to August 2018, more than 48,000 sentinel frozen $H$. halys eggs were exposed at six sites in the Canton Ticino to retrieve native egg parasitoids (Table 1). Overall 
Table 2 Sampling information, GenBank Accession Numbers and haplotypes for the T. japonicus included in this study (*)

\begin{tabular}{|c|c|c|c|c|c|c|}
\hline Collection code and sex & Country & Region & $\begin{array}{l}\text { Year of collection, } \\
\text { name of collector }\end{array}$ & Host & GenBank Accession Number & $\begin{array}{l}\text { Barcode } \\
\text { haplo- } \\
\text { type }\end{array}$ \\
\hline GBIFCH 00543446, ㅇ & Switzerland & Ticino & 2017, JS & Halyomorpha halys & MH919753* & H1 \\
\hline GBIFCH $00543447, q$ & Switzerland & Ticino & 2017, JS & H. halys & MH919754* & H1 \\
\hline GBIFCH 00543448, ㅇ & Switzerland & Ticino & 2017, JS & H. halys & MH919755* & $\mathrm{H} 1$ \\
\hline GBIFCH 00543449, ठ & Switzerland & Ticino & 2017, JS & H. halys & MH919756* & H1 \\
\hline GBIFCH 00543450, ठ̊ & Switzerland & Ticino & 2017, JS & H. halys & MH919757* & H1 \\
\hline GBIFCH $00543451, \lambda$ & Switzerland & Ticino & 2017, JS & H. halys & MH919758* & $\mathrm{H} 1$ \\
\hline CABI colony, $+(n=10)$ & China & Beijing & $2018, \mathrm{TH}$ & H. halys & MH919759* & $\mathrm{H} 2$ \\
\hline Tsp1 EBCL ${ }^{\mathrm{a}}, n a^{\mathrm{c}}$ & Japan & Tsukuba & $2012, \mathrm{KH}$ & na & MH919743 & $\mathrm{H} 1$ \\
\hline Tsp77, EBCL ${ }^{\mathrm{a}} n a$ & Japan & Tsukuba & $2012, \mathrm{KH}$ & $n a$ & MH919744 & H3 \\
\hline Tsp78, EBCL ${ }^{\mathrm{a}} n a$ & Japan & Tsukuba & $2012, \mathrm{KH}$ & na & MH919745 & $\mathrm{H} 3$ \\
\hline Tsp79, EBCL ${ }^{\mathrm{a}} n a$ & Japan & Tsukuba & $2012, \mathrm{KH}$ & $n a$ & MH919746 & $\mathrm{H} 3$ \\
\hline Tsp88, EBCL ${ }^{\mathrm{a}} n a$ & Japan & Tsukuba & $2012, \mathrm{KH}$ & $n a$ & MH919747 & $\mathrm{H} 3$ \\
\hline Tsp90, EBCL ${ }^{\mathrm{a}} n a$ & Japan & Tsukuba & $2012, \mathrm{KH}$ & $n a$ & MH919748 & $\mathrm{H} 3$ \\
\hline Tsp91, EBCL ${ }^{\mathrm{a}} n a$ & Japan & Tsukuba & $2012, \mathrm{KH}$ & $n a$ & MH919749 & $\mathrm{H} 3$ \\
\hline Tsp93, EBCL ${ }^{\mathrm{a}} n a$ & Japan & Tsukuba & $2012, \mathrm{KH}$ & $n a$ & MH919750 & $\mathrm{H} 3$ \\
\hline Tsp223, EBCL ${ }^{\mathrm{a}}+$ & Japan & Kanagawa & $2015, \mathrm{KH}$ & H. halys & MH919751 & $\mathrm{H} 3$ \\
\hline Tsp226 EBCL ${ }^{\mathrm{a}}$,, & Japan & Kanagawa & $2015, \mathrm{KH}$ & Plautia stali & MH919752 & $\mathrm{H} 3$ \\
\hline$n a, q$ & Japan & Kanagawa & 2012, TM & P. stali & AB847131-32,36 & $\mathrm{H} 4$ \\
\hline$n a$, 우 & Japan & Fukuoka & $2012, \mathrm{KM}$ & P. stali & AB847144-145 & H5 \\
\hline$n a,+$ q & Japan & Fukuoka & $2012, \mathrm{KM}$ & H. halys & AB908179-182 ${ }^{\mathrm{d}}$ & H5 \\
\hline$n a, n a$ & Japan & na & na & na & AB894834-35, AB894838-39 & H5 \\
\hline$n a$, ㅇ & Japan & Fukuoka & $2012, \mathrm{KM}$ & P. stali & $\mathrm{AB} 847129,130,137,143,146^{\mathrm{d}}$ & H6 \\
\hline$n a, n a$ & Japan & $n a$ & na & na & $\mathrm{AB} 894836,837,840,841^{\mathrm{e}}$ & H6 \\
\hline
\end{tabular}

${ }^{\mathrm{a} E B C L}$ DNA collection

${ }^{b}$ Name of collectors: KH, Kim Hoelmer (USDA-ARS), TM, Toshiharu Mita, KM, Kazunori Matsuo, JS, Judith Stahl (CABI), TH, Tim Haye (CABI)

${ }^{\mathrm{c}}$ Not available

${ }^{\mathrm{d}}$ Matsuo et al. (2014)

${ }^{\mathrm{e}}$ Matsuo and Hirose unpublished

parasitism was highly variable among sites and exposure dates, ranging from 0 to $17.3 \%$ (Table 1 ). Predation by sucking or chewing predators ranged from 0 to $2.2 \%$ and from 1.6 to $66.5 \%$, respectively (Table 1 ).

\section{Morphological identification of parasitoids}

Based on morphological analyses, Trissolcus individuals were identified as T. cultratus, T. semistriatus (Nees van Esenbeck) [syn. Trissolcus grandis (Thomson); Talamas et al. 2017], and the exotic T. japonicus (Fig. 1). In particular, T. japonicus was identified according to the following characters: vertex with hyperoccipital carina uniform and robust; area between hyperoccipital carena and medial ocellus coriaceous; longitudinal groove below preocellar pit; clypeus with 4 setae; orbital furrow expanded with medial margin well defined at intersection with malar sulcus; genal carina absent; mesoscutum with distinct notauli and without median mesoscutal carina; median lobe of mesoscutum without oblique rugulae; mesopleuron with episternal foveae forming a continuous line of cells from dorsal apex of postacetabular sulcus to mesopleural pit; laterotergite I without setae; T1 without sublateral setae; T2 with striae present throughout anterior half of tergite (Talamas et al. 2017). Other parasitoids were identified as A. bifasciatus and Telenomus turesis Walker (Fig. 1). In total, 12 T. japonicus adults were reared from three egg masses exposed at two dates in August 2017 in an apple orchard near Bellinzona, Canton of Ticino, Switzerland (site 1). In 2018, 17 individuals were reared from 7 egg masses at three different sites (site 1, 4, 6) (Table 1).

\section{Molecular confirmation}

The morphological identification of $T$. japonicus was confirmed by the molecular analysis performed by DISAFA. A 


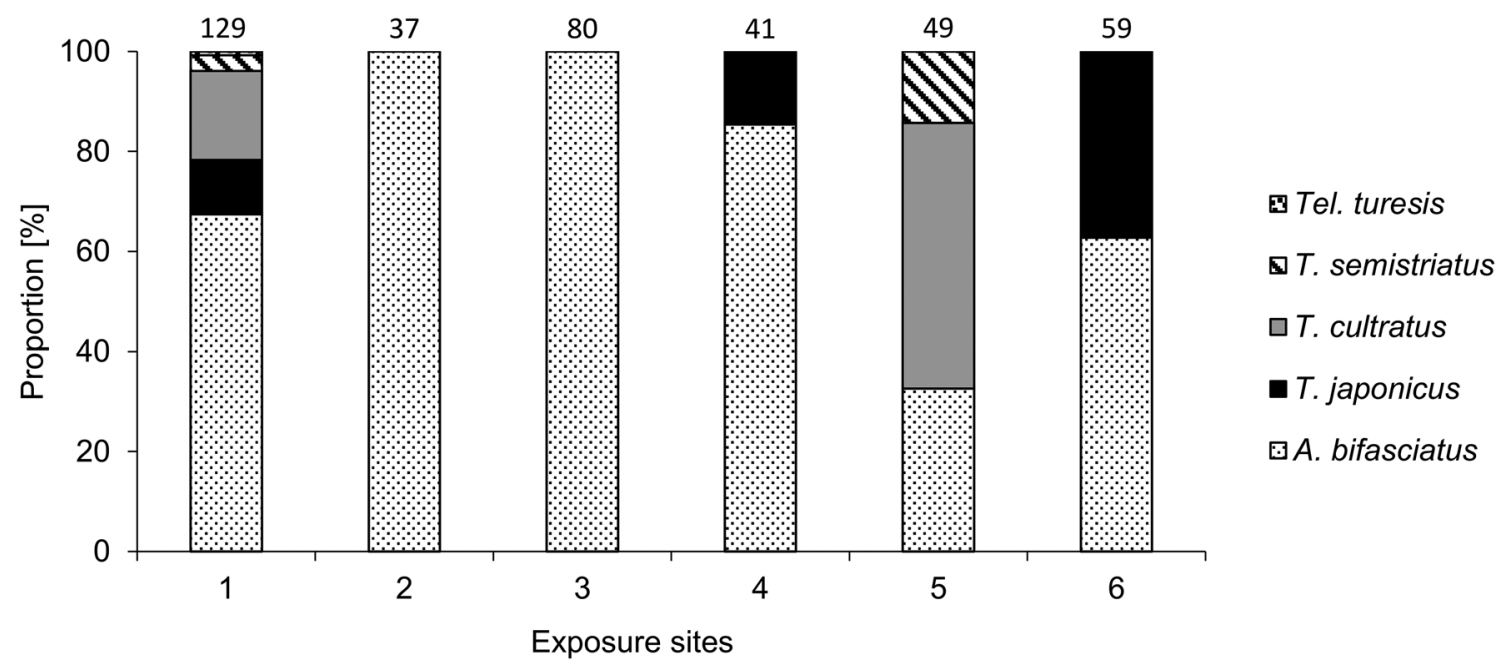

Fig. 1 Species composition of parasitoids reared from sentinel egg masses of Halyomorpha halys exposed at six sites in the Canton Ticino, Switzerland, in 2017 and 2018. Numbers of exposure sites

BLAST search showed the best similarity score (100\%) of our barcode sequence (612 bp in length) with T. japonicus (Accession No. AB971832).

\section{Genetic matching with Asian populations of Trissolcus japonicus}

The six analysed specimens recovered from the field yielded a single haplotype, H1. This haplotype was also correspond with locations listed in Table 1; total number of emerged parasitoids per site is displayed above bars

found in Tsukuba in Japan in 2012 (Fig. 2, Table 2) and is distant by one mutation from the two haplotypes ( $\mathrm{H} 3$ and H4) uncovered in Tsukuba and in Kanagawa in Japan (Fig. 2). The 10 specimens from the CABI colony yielded a single haplotype (H2) which is one mutation away from $\mathrm{H} 1$, indicating that the "Ticino populations" of T. japonicus did not escape accidentally from the CABI colony.

Fig. 2 Barcode haplotype network of the 58 T. japonicus analysed in this study. Each circle corresponds to one haplotype; circle size gives the proportion of individuals belonging to the haplotype. The colour inside each circle represents the geographical origin. Numbers correspond to the haplotype numbers. Hatch marks symbolize the number of mutations between haplotypes. The $\mathrm{H} 2$ haplotype from Beijing, China, represents the $\mathrm{CABI}$ colony

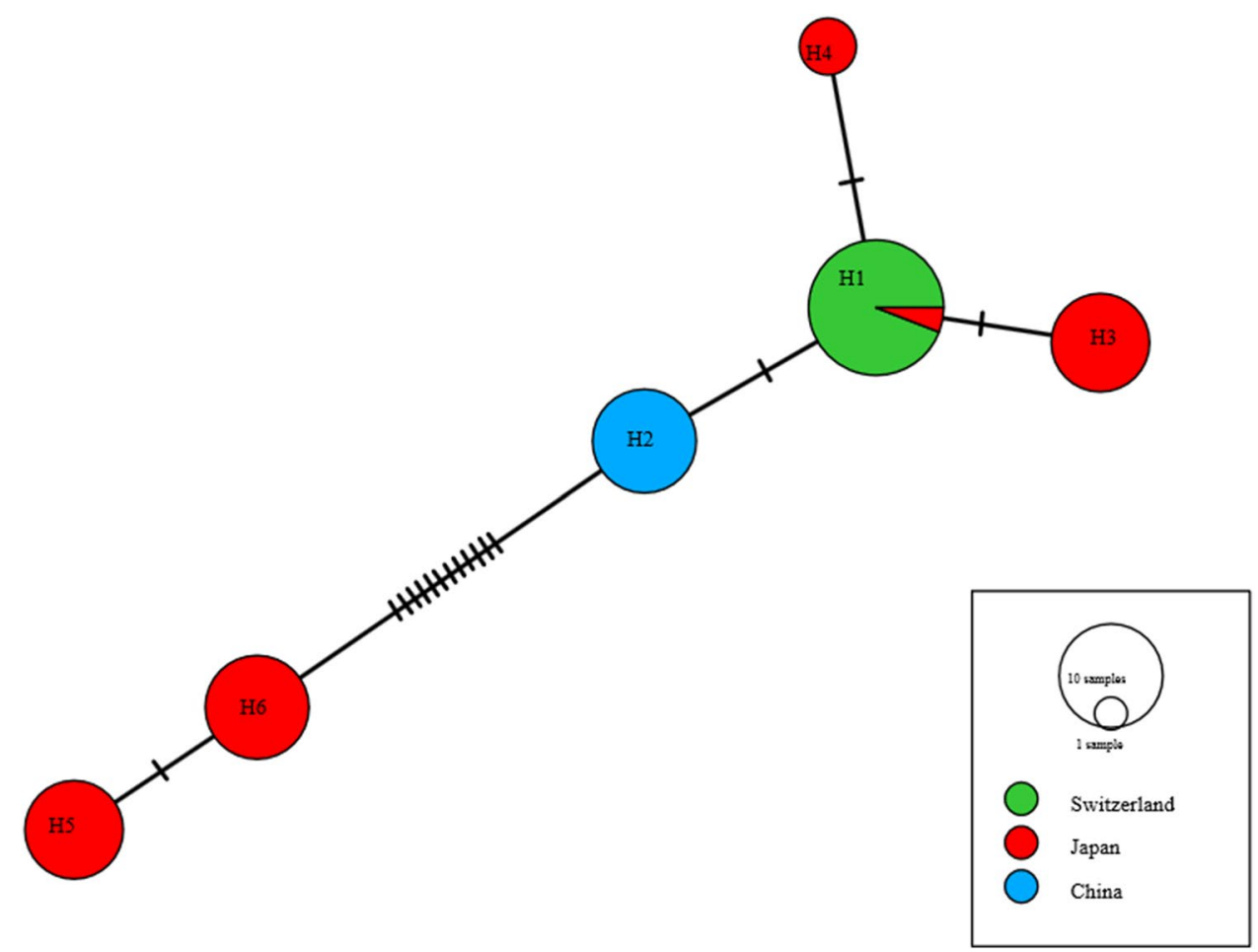




\section{Discussion}

Parasitism and predation of sentinel $H$. halys eggs by native European egg parasitoids and predators in southwestern Switzerland were generally low, which is consistent with previous studies in Europe and North America (e.g. Jones et al. 2014; Haye et al. 2015; Abram et al. 2017; Dieckhoff et al. 2017). Parasitoids recorded in the present study included two species, T. cultratus and A. bifasciatus, which have been recorded in earlier surveys in western and northern Switzerland (Haye et al. 2015), whereas T. semistriatus, Tel. turesis, and the exotic T. japonicus have not been previously reported from $H$. halys in Europe. To our best knowledge, this is also the first record of $T$. japonicus parasitizing $H$. halys eggs in apple orchards.

Recently, an increasing number of unintended introductions of biological control agents have been recorded (Servick 2018); however, it remains difficult to trace the origin of such introductions. Presumably, the majority are accidentally transported from their native range along with the pest. The actual pathways of entry for T. japonicus are unknown, but it is likely that either plants carrying parasitized egg masses of Asian Pentatomidae (H. halys or other hosts, see Zhang et al. 2017) or diapausing adults were introduced. As a result of population size bottlenecks and genetic drift in small founding populations as likely experienced by the T. japonicus "Ticino population," the level of haplotype diversity is reduced to a unique haplotype. Our haplotype analysis found a best match of the "Ticino populations" to Japanese populations so far, possibly indicating an introduction from Japan. Although our custom database is quite representative of the geographic distribution of $T$. japonicus, we cannot entirely exclude that the haplotype H1 may also be present in other parts of $T$. japonicus' native range, e.g. China or Korea, but has thus far remained unsampled. Tracing the source of introduction necessitates obtaining meaningful population structure information (Gariepy et al. 2015), requiring sometimes to use more than one locus. To add better resolution, a comprehensive phylogeographic study with the barcode is currently being undertaken, as well as with the microsatellite loci recently developed de novo for $T$. japonicus. Whether Switzerland was the actual country of introduction or whether T. japonicus was accidentally introduced into the climatically highly suitable northern Italy (Avila and Charles 2018) and is now spreading northwards into Switzerland remains unclear. However, considering that in 2016 Italy imported goods of more than twice the value from the region of China, Japan and the Republic of Korea than Switzerland (World Bank 2018), an introduction into Italy seems more likely, but future surveys in both regions may help to clarify the invasion pathways.
Field and laboratory studies in China and Japan showed that the host range of $T$. japonicus is not restricted to $H$. halys (Ryu and Hirashima 1984; Matsuo et al. 2016; Yang et al. 2009; Zhang et al. 2017), and fundamental host range studies conducted in Europe suggest that some native European Pentatomidae are suitable hosts for development (TH, LT, unpublished data). Accordingly, T. japonicus has the potential to directly impact native non-target stink bug species. However, the extent to which attacks may result in significant reductions in native stink bug populations will depend on various factors, such as habitat overlap, competition with native egg parasitoids, size and suitability of non-target host species. The adventive establishment of $T$. japonicus in Switzerland provides the opportunity to study the establishment and spread of this species in Europe, as well as to assess potential risks to native biodiversity under natural conditions. In particular, it will enable us to determine whether results from host range studies in Asia (Zhang et al. 2017) are able to predict the impact of this parasitoid outside of its native range.

It is too early to evaluate the impact of adventive $T$. japonicus populations on invasive $H$. halys populations in Switzerland as it has likely only recently arrived. However, based on the very high parasitism levels of $H$. halys eggs observed in Asia, its establishment may have the potential to reduce invasive stink bug densities below economic thresholds. Current $T$. japonicus populations are likely very low, which may explain why in both years it was only recovered in the second half of summer. In China, T. japonicus parasitizes $H$. halys eggs over the course of the entire season, from May to September, but parasitism is usually highest in August (Zhang et al. 2017). Continued studies exposing sentinel eggs and collecting natural egg masses will be necessary to determine the current distribution and spread of T. japonicus and to evaluate how egg mortality may affect populations of $H$. halys and non-target pentatomids in the near future.

\section{Authors' contribution}

JS, CM and TH conceived and designed research. LT, FT, MP and MCB identified the parasitoids. KH provided parasitoids from Asia for molecular analysis. All authors contributed to writing the manuscript and approved the final version.

Acknowledgements This project has received funding from the European Union's Horizon 2020 research and innovation programme under the Marie Sklodowska-Curie Grant Agreement No. 641456. Additional funding was provided by the Phytosanitary Service of the Canton Ticino, and the Associazione frutticoltori ticinesi. We would like to thank Darren Blackburn, Jessica Fraser, Chelsey Blackman, Taylor Kaye, Anna Grunsky, Christie Laing, Mariah Ediger, Lindsay 
Craig, and Giorgia Mattei for technical assistance. We are grateful to Cesare Bassi for allowing us to use his orchard for our studies. CABI is an international intergovernmental organization, and we gratefully acknowledge the core financial support from our member countries (and lead agencies) including the UK (Department for International Development), China (Chinese Ministry of Agriculture), Australia (Australian Centre for International Agricultural Research), Canada (Agriculture and Agri-Food Canada), Netherlands (Directorate-General for International Cooperation), and Switzerland (Swiss Agency for Development and Cooperation). See http://www.cabi.org/about-cabi/ who-we-work-with/key-donors/for full details.

\section{Compliance with ethical standards}

Conflict of interest The authors declare that they have no conflict of interest.

Human and animal rights This article does not contain any studies with human participants or animals (vertebrates) performed by any of the authors.

Informed consent Informed consent was obtained from all individual participants included in the study.

Open Access This article is distributed under the terms of the Creative Commons Attribution 4.0 International License (http://creativeco mmons.org/licenses/by/4.0/), which permits unrestricted use, distribution, and reproduction in any medium, provided you give appropriate credit to the original author(s) and the source, provide a link to the Creative Commons license, and indicate if changes were made.

\section{References}

Abram PK, Gariepy TD, Boivin G, Brodeur J (2014) An invasive stink bug as an evolutionary trap for an indigenous egg parasitoid. Biol Invasions 16:1387-1395

Abram PK, Hoelmer KA, Acebes-Doria A et al (2017) Indigenous arthropod natural enemies of the invasive brown marmorated stink bug in North America and Europe. J Pest Sci 90:1009-1020

Askew RR, Nieves-Aldrey JL (2004) Further observations on Eupelminae (Hymenoptera: Chalcidoidea, Eupelmidae) in the Iberian peninsula and Canary Islands, including descriptions of new species. Graellsia 60:27-39

Avila GA, Charles JG (2018) Modelling the potential geographic distribution of Trissolcus japonicus: a biological control agent of the brown marmorated stink bug, Halyomorpha halys. Biocontrol 63:505-518

Bosco L, Moraglio ST, Tavella L (2018) Halyomorpha halys, a serious threat for hazelnut in newly invaded areas. J Pest Sci 91(2):661-670

Cesari M, Maistrello L, Piemontese L, Bonini R, Dioli P, Lee W, Park CG, Partsinevelos GK, Rebecchi L, Guidetti R (2018) Genetic diversity of the brown marmorated stink bug Halyomorpha halys in the invaded territories of Europe and its patterns of diffusion in Italy. Biol Invasions 20:1073-1092

Costi E (2018) Biologia e monitoraggio in campo della cimice invasiva Halyomorpha halys in Italia e indagini su potenziali antagonisti naturali autoctoni. $\mathrm{PhD}$ thesis. Università Emilia Romagna

Dieckhoff C, Tatman KM, Hoelmer KA (2017) Natural biological control of Halyomorpha halys by native egg parasitoids: a multi-year survey in northern Delaware. J Pest Sci 90(4):1143-1158
Folmer O, Black M, Hoeh W, Lutz R, Vrijenhoek R (1994) DNA primers for amplification of mitochondrial cytochrome c oxidase subunit I from diverse metazoan invertebrates. Mol Mar Biol Biotechnol 3:294-299

Ganjisaffar F, Talamas EJ, Bon MC, Gonzalez L, Brown BV, Perring TM (2018) Trissolcus hyalinipennis Rajmohana \& Narendran (Hymenoptera, Scelionidae), a parasitoid of Bagrada hilaris (Burmeister) (Hemiptera, Pentatomidae) emerges in North America. J Hymenopt Res 65:111-130

Gariepy TD, Haye T, Zhang J (2014) A molecular diagnostic tool for the preliminary assessment of host-parasitoid associations in biological control programmes for a new invasive pest. Mol Ecol 23:3912-3924

Gariepy TD, Bruin A, Haye T, Milonas P, Vétek G (2015) Occurrence and genetic diversity of new populations of Halyomorpha halys in Europe. J Pest Sci 88:451-460

Giantsis I, Chaskopoulou A, Bon MC (2015) Mild-vectolysis: a nondestructive DNA extraction method for vouchering sand flies and mosquitoes. J Med Entomol 53:692-695

Haye T, Fischer S, Zhang J, Gariepy T (2015) Can native egg parasitoids adopt the invasive brown marmorated stink bug, Halyomorpha halys (Heteroptera: Pentatomidae), in Europe? J Pest Sci 88:693-705

Hedstrom C, Lowenstein D, Andrews H, Bai B, Wiman N (2017) Pentatomid host suitability and the discovery of introduced populations of Trissolcus japonicus in Oregon. J Pest Sci 90:1169-1179

Hoebeke ER, Carter ME (2003) Halyomorpha halys (Stål) (Heteroptera: Pentatomidae): a polyphagous plant pest from Asia newly detected in North America. Proc Entomol Soc Wash 105:225-237

Johnson NF (1984) Systematics of Nearctic Telenomus: classification and revisions of the podisi and phymatae species groups (Hymenoptera: Scelionidae). Bull Ohio Biol Surv 6:1-113

Jones AL, Jennings DE, Hooks CR, Shrewsbury PM (2014) Sentinel eggs underestimate rates of parasitism of the exotic brown marmorated stink bug, Halyomorpha halys. Biol Control 78:61-66

Kozlov MA, Kononova SV (1983) Telenominae of the fauna of the USSR. Nauka, Leningrad

Lee D-H, Short BD, Joseph SV, Bergh JC, Leskey TC (2013) Review of the biology, ecology, and management of Halyomorpha halys (Hemiptera: Pentatomidae) in China, Japan, and the Republic of Korea. Environ Entomol 42:627-641

Leigh JW, Bryant D (2015) POPART: full-feature software for haplotype network construction. Methods Ecol Evol 6:1110-1116

Leskey TC, Nielsen AL (2018) Impact of the invasive brown marmorated stink bug in North America and Europe: history, biology, ecology, and management. Annu Rev Entomol 63:599-618

Maistrello L, Vaccari G, Caruso S et al (2017) Monitoring of the invasive Halyomorpha halys, a new key pest of fruit orchards in northern Italy. J Pest Sci 90:1231-1244

Matsuo K, Hirose Y, Johnson NF (2014) A taxonomic issue of two species of Trissolcus (Hymenoptera: Platygastridae) parasitic on eggs of the brown-winged green bug, Plautia stali (Hemiptera: Pentatomidae): resurrection of T. plautiae, a cryptic species of T. japonicus revealed by morphology, reproductive isolation and molecular evidence. Appl Entomol Zool 49:385-394

Matsuo K, Honda T, Itoyama K, Toyama M, Hirose Y (2016) Discovery of three egg parasitoid species attacking the shield bug Glaucias subpunctatus (Hemiptera: Pentatomidae). Jpn J Appl Entomol Zool 60:43-45

Milnes JM, Wiman NG, Talamas EJ, Brunner JF, Hoelmer KA, Buffington ML, Beers EH (2016) Discovery of an exotic egg parasitoid of the brown marmorated stink bug, Halyomorpha halys (Stål) in the Pacific Northwest. Proc Entomol Soc Wash 118:466-470

Morrison WR III, Mathews CR, Leskey TC (2016) Frequency, efficiency, and physical characteristics of predation by generalist 
predators of brown marmorated stink bug (Hemiptera: Pentatomidae) eggs. Biol Control 97:120-130

Morrison WR III, Blaauw BR, Nielsen AL, Talamas E, Leskey TC (2018) Predation and parasitism by native and exotic natural enemies of Halyomorpha halys (Stål) (Hemiptera: Pentatomidae) eggs augmented with semiochemicals and differing host stimuli. Biol Control 121:140-150

Qiu LF, Yang ZQ, Tao WQ (2007) Biology and population dynamics of Trissolcus halyomorphae. Sci Silvae Sin 43:62-65

Rice KB, Bergh CJ, Bergmann EJ, Biddinger DJ, Dieckhoff C, Dively G, Fraser H, Gariepy T, Hamilton G, Haye T, Herbert A (2014) Biology, ecology, and management of brown marmorated stink bug (Hemiptera: Pentatomidae). J Integr Pest Manag 5:A1-A13

Roversi PF, Marianelli L, Costi E, Maistrello L, Sabbatini PG (2016) Searching for native egg-parasitoids of the invasive alien species Halyomorpha halys Stål (Heteroptera Pentatomidae) in Southern Europe. Redia 99:63-70

Ryu J, Hirashima Y (1984) Taxonomic studies on the genus Trissolcus Ashmead of Japan and Korea (Hymenoptera, Scelionidae). J Fac Agric Kyushu Univ 29:35-58

Schlaepfer MA, Sherman PW, Blossey B, Runge MC (2005) Introduced species as evolutionary traps. Ecol Lett 8(3):241-246

Servick K (2018) Control freaks. Science 361:542-545

Stahl J, Babendreier D, Haye T (2018) Using the egg parasitoid Anastatus bifasciatus against the invasive brown marmorated stink bug in Europe-can non-target effects be ruled out? J Pest Sci 91:1005-1017

Talamas EJ, Herlihy MV, Dieckhoff C, Hoelmer KA, Buffington M, Bon MC, Weber DC (2015) Trissolcus japonicus (Ashmead) (Hymenoptera, Scelionidae) emerges in North America. J Hymenopt Res 43:119

Talamas EJ, Buffington ML, Hoelmer K (2017) Revision of Palearctic Trissolcus Ashmead (Hymenoptera, Scelionidae). In: Talamas EJ, Buffington ML (Eds) Advances in the systematics of Platygastroidea. J Hymenopt Res 56:3-185

United States Apple Association (2010) Asian pest inflicting substantial losses, raising alarm in eastern apple orchards. Apple News 41:488

World Bank (2018) Data retrieved October 15, 2018, from World Integrated Trade Solution. UNSD Commodity Trade (COMTRADE) database

Yang Z-Q, Yao Y-X, Qiu L-F, Li Z-X (2009) A new species of Trissolcus (Hymenoptera: Scelionidae) parasitizing eggs of Halyomorpha halys (Heteroptera: Pentatomidae) in China with comments on its biology. Ann Entomol Soc Am 102:39-47

Zhang J, Zhang F, Gariepy T, Mason P, Gillespie D, Talamas E, Haye $\mathrm{T}$ (2017) Seasonal parasitism and host specificity of Trissolcus japonicus in northern China. J Pest Sci 90:1127-1141 